\title{
Allele-specific regulation of FGFR2 expression is cell type-dependent and may increase breast cancer risk through a paracrine stimulus involving FGF10
}

\author{
Petra EA Huijts ${ }^{1 *}$, Minka van Dongen², Moniek CM de Goeij ${ }^{2}$, Adrian J van Moolenbroek², Freek Blanken², \\ Maaike PG Vreeswijk ${ }^{2}$, Esther M de Kruijf ${ }^{3}$, Wilma E Mesker ${ }^{3}$, Erik W van Zwet $^{4}$, Rob AEM Tollenaar ${ }^{3}$, \\ Vincent THBM Smit ${ }^{5}$, Christi J van Asperen ${ }^{1}$ and Peter Devilee ${ }^{2,5}$
}

\begin{abstract}
Introduction: SNPs rs2981582 and rs2981578, located in a linkage disequilibrium block (LD block) within intron 2 of the fibroblast growth factor receptor 2 gene (FGFR2), are associated with a mildly increased breast cancer risk. Allele-specific regulation of FGFR2 mRNA expression has been reported previously, but the molecular basis for the association of these variants with breast cancer has remained elusive to date.

Methods: mRNA levels of FGFR2 and three fibroblast growth factor genes (FGFs) were measured in primary fibroblast and epithelial cell cultures from 98 breast cancer patients and correlated to their rs2981578 genotype. The phosphorylation levels of downstream FGFR2 targets, FGF receptor substrate $2 \alpha$ (FRS2 $\alpha$ ) and extracellular signalregulated kinases 1 and 2 (ERK1/2), were quantified in skin fibroblasts exposed to FGF2. Immunohistochemical markers for angiogenesis and lymphocytic infiltrate were semiquantitatively assessed in 25 breast tumors.

Results: The risk allele of rs 2981578 was associated with increased FGFR2 mRNA levels in skin fibroblasts, but not in skin epithelial cell cultures. FGFR2 mRNA levels in skin fibroblasts and breast fibroblasts correlated strongly in the patients from whom both cultures were available. Tumor-derived fibroblasts expressed, on average, eight times more FGFR2 mRNA than the corresponding fibroblasts from normal breast tissue. Fibroblasts with higher FGFR2 mRNA expression showed more FRS2 $\alpha$ and ERK1/2 phosphorylation after exposure to FGF2. In fibroblasts, higher FGFR2 expression correlated with higher FGF10 expression. In 25 breast tumors, no associations between breast tumor characteristics and fibroblast FGFR2 mRNA levels were found.

Conclusions: The influence of rs2981578 genotypes on FGFR2 mRNA expression levels is cell type-dependent. Expression differences correlated well with signaling levels of the FGFR2 pathway. Our results suggest that the increased breast cancer risk associated with SNP rs2981578 is due to increased FGFR2 signaling activity in stromal fibroblasts, possibly also involving paracrine FGF10 signaling.
\end{abstract}

\section{Introduction}

Several genome-wide association studies have shown that the minor allele of SNP rs2981582, located in intron 2 of the fibroblast growth factor receptor 2 gene (FGFR2), is associated with increased breast cancer risk [1-6]. The odds ratios (ORs) for this SNP are 1.23 in heterozygotes and 1.63 in homozygotes for the minor

\footnotetext{
* Correspondence: p.e.a.huijts@lumc.nl

'Department of Clinical Genetics, Leiden University Medical Center, PO Box 9600, 2300 RC Leiden, The Netherlands

Full list of author information is available at the end of the article
}

allele [1,2], but attributable risk is high because of the high frequency of the risk allele population. Fine-scale genetic mapping and resequencing of the region surrounding rs2981582 resulted in the identification of up to eight variants in a linkage disequilibrium block (LD block) within intron 2 of FGFR2 most strongly associated with increased breast cancer risk, including SNP rs2981578 [1,5,7]. The location of this LD block suggests that these variations somehow modify the functioning of FGFR2.

\section{() Biomed Central}

(C) 2011 Huijts et al.; licensee BioMed Central Ltd. This is an open access article distributed under the terms of the Creative Commons Attribution License (http://creativecommons.org/licenses/by/2.0), which permits unrestricted use, distribution, and reproduction in any medium, provided the original work is properly cited. 
Meyer et al. [7] have shown that two SNPs within this LD block, one of them being rs2981578, alter the DNA binding affinity of octamer-binding transcription factor 1 (Oct-1), runt-related transcription factor 2 (Runx2) and CCAAT/enhancer binding protein $\beta(\mathrm{C} / \mathrm{EBP} \beta)$. Accordingly, increased expression of FGFR2 mRNA was observed in total RNA isolated from breast tumors of patients homozygous for the risk allele as compared to homozygotes for the major allele [7]. Paradoxically, Sun et al. [8] recently reported decreased expression of FGFR2 mRNA in normal breast tissue of homozygotes for the risk allele.

FGFR2 is one of five fibroblast growth factor (FGF) receptors known in humans to be involved in various signaling pathways that regulate processes such as cell growth, apoptosis and differentiation. Two isoforms, FGFR2-IIIb and FGFR2-IIIc, are the result of mutually exclusive alternative splicing of exon 9 or 10 of FGFR2. Isoform IIIb is present on epithelial cells and binds ligands FGF3, FGF7, FGF10 and FGF22 and isoform IIIc is present on mesenchymal cells and binds FGF2, FGF4, FGF6, FGF9, FGF17 and FGF18 [9]. Binding of a ligand to the receptor can activate several signaling pathways, including the mitogen-activated protein kinase (MAPK) pathway $[10,11]$.

Downregulation of FGFR2 protein has been reported in up to $67 \%$ of breast tumors [12], whereas amplification of FGFR2 and upregulation of FGFR2 mRNA expression have been reported in less than $10 \%$ of breast tumors $[10,13]$. Somatic FGFR2 mutations are rare in breast cancer [14]. A switch from the IIIb to the IIIc isoform in tumor cells, resulting in activation of the receptor by other FGFs, has been reported in a subset of prostate cancers and in a few breast cancer cell lines [15-17].

To further unravel the mechanisms by which the SNPs in intron 2 of FGFR2 increase breast cancer risk, and to address the heterogeneous cellular composition of breast tumors, we studied the expression of FGFR2 mRNA in relation to the rs 2981578 genotype in fibroblasts and epithelial cells cultured from breast tissue. We also compared the FGFR2 mRNA expression in fibroblasts derived from normal skin tissue, normal breast tissue and breast tumor tissue. Furthermore, we explored the functional implications of different levels of FGFR2 expression at the cellular level by studying the downstream MAPK pathway. Finally, we compared histological characteristics between tumors of patients with high and low FGFR2 levels.

\section{Materials and methods Patients}

Breast tissue was obtained from 98 women who had undergone breast cancer-related surgery at the Leiden University Medical Center (LUMC) from February 2006 until December 2010 (patient demographics are given in Table 1). According to the Dutch Medical Treatment
Act, anonymized samples obtained during medical treatment may be used in medical research if the patient does not object to this "secondary use" (opt-out system). Samples were coded in such a way that identifying information was not accessible by the researcher, but samples still could be linked to pathology reports by authorized clinicians. The use of residual material for this study was approved by the Department of Pathology of the LUMC (code OP 25-06). The study protocol was compliant with the Code of Conduct issued by the Dutch Federation of Medical Scientific Societies.

\section{Tissue culture}

Fibroblasts and epithelial cells were cultured separately from skin tissue, normal breast tissue or tumor tissue by cutting the tissue patches into $2-\mathrm{mm} \times 2-\mathrm{mm}$ pieces. Tissue patches were allowed to attach to the culture flask for 30 minutes, then we added DMEM/F12 medium (1:1 dilution; GIBCO/Invitrogen, Breda, the Netherlands) supplemented with 20\% FCS (Bodinco, Alkmaar, The Netherlands) and antibiotics. Cells were grown at $37^{\circ} \mathrm{C}$ in $5 \% \mathrm{CO}_{2}$. Each fibroblast culture was expanded in medium supplemented with 10\% FCS and antibiotics. Epithelial cells were grown in HuMEC Ready Medium (GIBCO/Invitrogen) or in DermaLife K Serum-Free Keratinocyte Culture Medium (Lifeline Cell Technology, Walkersville, MD, USA) (see also Table 2). The morphology of primary cultures was in agreement with the morphology of established epithelial and mesenchymal cell lines (Figure S1 in Additional file 1).

\section{Genotyping}

Genomic DNA was isolated using the Wizard Genomic DNA Purification Kit (Promega, Leiden, The Netherlands) according to the manufacturer's instructions. Four SNPs in intron 2 of FGFR2 were genotyped (Table 3).

\section{Table 1 Characteristics of the patient cohort ${ }^{\mathrm{a}}$}

\begin{tabular}{lc}
\hline Characteristics & Data \\
\hline Total number of patients & 98 \\
BRCA1/2 mutation carriers, $n(\%)$ & $10(10 \%)$ \\
Diagnosis & $55( \pm 14)$ \\
$\quad$ Mean age at diagnosis ${ }^{\text {b }}$, years & \\
( \pm SD) & 83 \\
Invasive breast cancer, $n$ & 8 \\
In situ breast cancer, $n$ & 7 \\
$\quad$ Prophylactic surgery, no cancer, & \\
$n$ & \\
Tumor characteristics $(n=91)$ & 54 positive, 20 negative, 17 \\
ER status & unknown \\
\hline
\end{tabular}

${ }^{a}$ SD: standard deviation; ER: estrogen receptor. ${ }^{b}$ Age at diagnosis of breast cancer. The seven patients who underwent prophylactic surgery were excluded from this analysis. 
Table 2 Culture medium used to culture skin epithelial cells ${ }^{a}$

\begin{tabular}{|c|c|}
\hline Culture ID & Medium used \\
\hline 46 & HUMEC \\
\hline 47 & HUMEC \\
\hline 52 & HUMEC \\
\hline 54 & HUMEC \\
\hline 55 & HUMEC \\
\hline 57 & HUMEC \\
\hline 58 & HUMEC \\
\hline 59 & HUMEC \\
\hline 64 & HUMEC \\
\hline 65 & HUMEC \\
\hline 69 & DermaLife \\
\hline 70 & DermaLife \\
\hline 77 & DermaLife \\
\hline 83 & HUMEC \\
\hline 100 & HUMEC \\
\hline 103 & DermaLife \\
\hline 132 & DermaLife \\
\hline 140 & DermaLife \\
\hline 143 & DermaLife \\
\hline 152 & DermaLife \\
\hline 157 & DermaLife \\
\hline 163 & DermaLife \\
\hline 170 & DermaLife \\
\hline 189 & DermaLife \\
\hline 209 & DermaLife \\
\hline
\end{tabular}

${ }^{a}$ Culture ID refers to the unique number assigned to a patient during the process of sample anonymization; HuMEC $=$ HuMEC Ready Medium (GIBCO/ Invitrogen, Breda, The Netherlands); DermaLife = DermaLife K Serum-Free Keratinocyte Culture Medium (Lifeline Cell Technology, Walkersville, MD, USA).

\section{Quantitative real-time PCR}

Total RNA was isolated from exponentially growing fibroblasts or epithelial cells using NucleoSpin RNA II Kit (Clontech, St-Germain-en-Laye, France) according to the manufacturer's instructions. During isolation, a 30-minute DNase treatment was performed to ensure complete degradation of contaminating DNA.

A detailed description of the $\mathrm{RT}$ reaction and quantitative PCR (qPCR) conditions can be found in the supplementary methods section (Additional file 2). Briefly, qPCR was performed to analyze the expression of a specific gene (Table 4) using the Bio-Rad iCycler thermal cycler and the iQ SYBR Green Supermix (Bio-Rad Laboratories, Hercules, CA, USA) according to the manufacturer's recommendations. Each gene was measured at least twice in each sample. As reference genes, the TATA box binding protein $(T B P)$ and heterogeneous nuclear ribonucleoprotein M (HNRPM or HNRNPM) (fibroblasts) genes or signal recognition particle receptor (SRPR), HNRPM and $T B P$ (epithelial cells) genes were used.

\section{Fragment analysis}

Isoforms FGFR2-IIIb and FGFR2-IIIc differ by the alternative splicing in of either exon 9 or exon 10 into the mature mRNA, resulting in a difference of $3 \mathrm{bp}$ in length of the mature mRNA. A PCR fragment of $297 \mathrm{bp}$ for FGFR2-IIIb or 300 bp for FGFR2-IIIc mRNA was amplified by PCR with 38 cycles and an annealing temperature of $70^{\circ} \mathrm{C}$ using the 6-carboxyfluorescein-labeled forward primer 5'-GTGGAAAAGAACGGCAGTAAATACG-3' and reverse primer 5'-CACCATACAGGCGATTAAGAAGACC-3' located in exons 8 and 11.

Fragment analysis was performed on cDNA from 14 skin epithelial cell cultures and 52 skin fibroblast cultures using the 3730xl DNA Analyzer (Applied Biosystems, Carlsbad, CA, USA) and the GeneScan 400HD ROX Size Standard (Applied Biosystems).

\section{Measuring FGFR2 protein levels}

FGFR2 protein levels were analyzed in seven exponentially growing fibroblast cultures with high $(n=3)$ or

Table 3 Primers used to genotype four SNPs in FGFR2 ${ }^{a}$

\begin{tabular}{|c|c|c|c|c|c|}
\hline SNP & Primer & Primer sequence $\left(5^{\prime}\right.$ to $\left.3^{\prime}\right)$ & $\begin{array}{l}\text { Product } \\
\text { length }\end{array}$ & $\begin{array}{l}\text { Annealing } \\
\text { temperature }\end{array}$ & Further analysis \\
\hline \multirow[t]{2}{*}{ rs10736303 } & $F$ & AGGGACAAATACTCCGCACA & $405 \mathrm{bp}$ & $50^{\circ} \mathrm{C}$ & Sanger sequencing \\
\hline & $\mathrm{R}$ & AGCCATCCAGCATGTTTCTC & & & \\
\hline \multirow[t]{2}{*}{ rs2981578 } & $F$ & TGACTCTTCAAAGTTTGTTTGTIT & $295 \mathrm{bp}$ & $50^{\circ} \mathrm{C}$ & $\begin{array}{l}\text { Restriction enzyme Acil (New England Biolabs, Ipswich, } \\
\text { MA, USA) }\end{array}$ \\
\hline & $\mathrm{R}$ & GAGGAAAGGTTCCCCACACT & & & \\
\hline \multirow[t]{2}{*}{ rs2981582 } & $F$ & AGCTCAGCTTACCCCAGACA & $215 \mathrm{bp}$ & $58^{\circ} \mathrm{C}$ & $\begin{array}{l}\text { Restriction enzyme Acil (New England Biolabs, Ipswich, } \\
\text { MA, USA) }\end{array}$ \\
\hline & $\mathrm{R}$ & CGTGAGCCAAGCCTCTACTT & & & \\
\hline \multirow[t]{2}{*}{ rs7895676 } & $F$ & CAGGTGCGGTGGCTCATGTC & $345 \mathrm{bp}$ & $67^{\circ} \mathrm{C}$ & Sanger sequencing \\
\hline & $\mathrm{R}$ & GACTTCAATGGCGGGACTCC & & & \\
\hline
\end{tabular}

${ }^{\mathrm{a}}$ FGFR2: fibroblast growth factor receptor 2 gene; F: forward primer; R: reverse primer; bp: base pair. For each SNP, the forward and reverse primer sequences, the length of the resulting PCR product and the annealing temperature used during PCR are shown. Also shown is the technique that was used on the resulting PCR fragment to genotype the SNPs. 
Table 4 Primers used during real-time PCR analyses ${ }^{a}$

\begin{tabular}{|c|c|c|c|c|c|c|}
\hline $\begin{array}{l}\text { Gene and } \\
\text { (GenelD) }^{\mathbf{b}}\end{array}$ & $\begin{array}{l}\text { Sequence } \\
\text { ID }\end{array}$ & Primer & Primer sequence $\left(5^{\prime}\right.$ to $\left.3^{\prime}\right)$ & $\begin{array}{l}\text { Product } \\
\text { length }\end{array}$ & $\begin{array}{l}\text { Distance from poly(A) } \\
\text { tail }^{\mathrm{c}}\end{array}$ & $\begin{array}{l}\text { Exon-exon } \\
\text { boundary }\end{array}$ \\
\hline FGF2 & NM_002006.4 & $\mathrm{F}$ & ACCTGCAGACTGCTITTGCCCA & $91 \mathrm{bp}$ & $1,731 \mathrm{bp}$ & No \\
\hline$(2247)$ & & $\mathrm{R}$ & GGTGCCACGTGAGAGCAGAGC & & & \\
\hline FGF7 & NM_002009.3 & $\mathrm{F}$ & CTCAACGGCAAGTTTCCCTCCCTITC & $80 \mathrm{bp}$ & $1,701 \mathrm{bp}$ & No \\
\hline$(2252)$ & & R & GCCTTCCAGGATTTGCTGGCCC & & & \\
\hline FGF10 & NM_004465.1 & $\mathrm{F}$ & 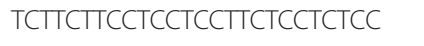 & 148 bp & $325 \mathrm{bp}$ & No \\
\hline$(2255)$ & & $\mathrm{R}$ & TCCCGCTGACCTTCCCGTTCTTCTC & & & \\
\hline FGFR2 ${ }^{d}$ & NM_000141.4 & $\mathrm{F}$ & GTCAGTGAGAACAGTAACAACAAG & 192 bp & $3,368 \mathrm{bp}$ & Yes \\
\hline$(2263)$ & & $\mathrm{R}$ & GTAGCCTCCAATGCGATGC & & & \\
\hline GADPH & NM_002046.3 & $\mathrm{F}$ & TTCCAGGAGCGAGATCCCT & 175 bp & $805 \mathrm{bp}$ & Yes \\
\hline$(2597)$ & & $\mathrm{R}$ & CACCCATGACGAACATGGG & & & \\
\hline HMBS & NM_000190.3 & $\mathrm{F}$ & CTGGTAACGGCAATGCGGCT & 338 bp & $1010 \mathrm{bp}$ & Yes \\
\hline$(3145)$ & & R & GCAGATGGCTCCGATGGTGA & & & \\
\hline HNRPM & NM_005968.3 & $\mathrm{F}$ & GAGGCCATGCTCCTGGG & $85 \mathrm{bp}$ & $440 \mathrm{bp}$ & Yes \\
\hline$(4670)$ & & $\mathrm{R}$ & TITAGCATCTTCCATGTGAAATCG & & & \\
\hline HPRT1 & NM_000194.2 & $\mathrm{F}$ & TGACACTGGCAAAACAATGCA & $94 \mathrm{bp}$ & $742 \mathrm{bp}$ & Yes \\
\hline$(3251)$ & & R & GGTCCTITTCACCAGCAAGCT & & & \\
\hline$S R P R$ & NM_003139.2 & $\mathrm{F}$ & CATTGCTITGCACGTAACCAA & $70 \mathrm{bp}$ & $1,308 \mathrm{bp}$ & Yes \\
\hline$(6734)$ & & $\mathrm{R}$ & ATTGTCTTGCATGCGGCC & & & \\
\hline TBP & NM_003194.3 & $\mathrm{F}$ & CACGAACCACGGCACTGATT & $89 \mathrm{bp}$ & 905 bp & Yes \\
\hline (6908) & & R & TITTCTTGCTGCCAGTCTGGAC & & & \\
\hline
\end{tabular}

${ }^{a}$ FGF: fibroblast growth factor gene; FGFR: fibroblast growth factor receptor gene; GAPDH: glyceraldehyde 3-phosphate dehydrogenase gene; HMBS: hydroxymethylbilane synthase gene; HNRPM: heterogeneous nuclear ribonucleoprotein M gene; HPRT1: hypoxanthine phosphoribosyltransferase 1 gene; SRPR: signal recognition particle receptor gene; TBP: TATA box binding protein gene; F: forward primer; R: reverse primer; bp: base pair. For each gene, the forward and reverse primer sequences, the length of the resulting PCR product (using CDNA as template) and the distance from the poly(A) tail are shown, as is the

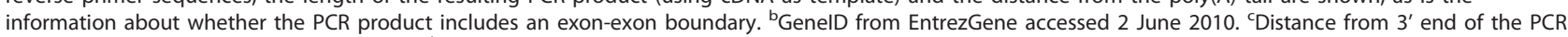
product to $5^{\prime}$ beginning of the poly(A) tail. 'Primer set for FGFR2 is in a region of FGFR2 that is present in both FGFR2 IIlb and FGFR2 IIIc.

low $(n=4)$ FGFR2 mRNA levels. Total protein isolation and Western blot analysis are described in detail in the supplementary methods section (Additional file 2). Each sample was measured twice on separate gels. The primary and secondary antibodies used are given in Table 5. The Odyssey Infrared Imaging System and Odyssey 3.0 software (LI-COR Biotechnology, Cambridge, UK) were used to visualize and identify the bands.

\section{Analyzing the phosphorylation of downstream FGFR2 targets}

Five skin fibroblast cultures with high FGFR2 mRNA expression and five skin fibroblast cultures with low FGFR2 mRNA expression were randomly selected. In each experiment, one culture with high mRNA expression and one culture with low mRNA expression were compared. In each well of a six-well plate, $5 \times 10^{5}$ fibroblasts from the full cell culture flasks were seeded and $10 \%$ FCS medium was added. The cells were allowed to attach to the well bottom for 24 hours and were then starved in $0.5 \%$ FCS medium for 12 hours. Cells were subsequently exposed to 0 or $20 \mathrm{ng}$ of FGF2 (basic fibroblast growth factor, 9952; Cell Signaling Technology, Danvers, MA, USA) in $0.5 \mathrm{~mL}$ of $0.5 \%$ FCS medium for 10 minutes. This length of time was chosen because in an initial experiment phosphorylation levels peaked at about 10 minutes (Figure S2 in Additional file 3).

Total protein was then isolated, and Western blot analysis was performed to assess the phosphorylation of downstream targets of FGFR2 as described in more detail in the supplementary methods section (Additional file 2). The primary and secondary antibodies that were used are given in Table 5. Phosphorylation levels after 10 minutes of exposure were normalized to phosphorylation levels before exposure.

\section{Determining the stroma percentage within the primary tumor}

Routine $\mathrm{H}$ \& E-stained histological tumor sections were obtained from the Department of Pathology for 50 of the 68 patients from whom skin fibroblast cultures were available. The stroma percentage within the primary tumor was estimated by two researchers as previously described [18].

\section{Immunohistochemistry}

For the immunohistochemical analyses, patients were selected for being either homozygous for the risk allele and having high FGFR2 mRNA expression $(n=11)$ or for being homozygous for the major allele and having 
Table 5 Antibodies used during Western blot analyses ${ }^{a}$

\begin{tabular}{|c|c|c|c|c|}
\hline Antigen targeted & Antibody (catalog number, manufacturer) & Clonality & Dilution & Origin \\
\hline \multicolumn{5}{|l|}{ Primary antibodies } \\
\hline FGFR2 & Bek C-17 (sc-122, SZ) & Polyclonal & 1 in 500 & Rabbit \\
\hline$\alpha$-tubulin & Anti- $\alpha$-tubulin $(T 6199, S A)$ & Monoclonal & 1 in 8,000 & Mouse \\
\hline ERK $1 / 2$ & p44/42 MAPK antibody $(9102$, CS) & Polyclonal & 1 in 100 & Rabbit \\
\hline Phosphorylated ERK1/2 & Phospho-p44/42 MAPK antibody (4377, CS) & Monoclonal & 1 in 200 & Rabbit \\
\hline FRS2 $\alpha$ & FRS2 H-91 (sc-8318, SZ) & Polyclonal & 1 in 50 & Rabbit \\
\hline Phosphorylated FRS2 $\alpha$ & Phospho-FRS2- $\alpha$ antibody (3864, CS) & Polyclonal & 1 in 50 & Rabbit \\
\hline \multicolumn{5}{|l|}{ Secondary antibodies } \\
\hline Mouse IgG & IRDye 680 anti-mouse lgG $(926-32220$, LC) & Polyclonal & 1 in 7,500 & Goat \\
\hline Rabbit lgG & IRDye 800CW anti-rabbit IgG (926-32211, LC) & Polyclonal & 1 in 5,000 & Goat \\
\hline
\end{tabular}

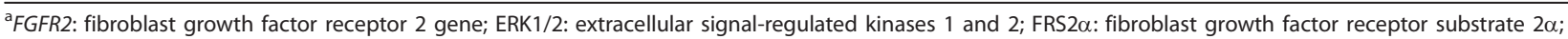
IgG: immunoglobulin G; MAPK: mitogen-activated protein kinase. Manufacturer names are abbreviated as follows: SZ: Santa Cruz Biotechnology, Santa Cruz, CA, USA; SA: Sigma-Aldrich, Zwijndrecht, The Netherlands; CS: Cell Signaling Technology, Danvers, MA, USA; LC, LI-COR Biosciences, Cambridge, UK. For each antibody, the target, manufacturer, clonality, dilution used during Western blot analysis and origin are given.

low FGFR2 mRNA expression $(n=14)$. Tissue sections were stained using antibodies to detect the presence of microvessels (CD31) and T lymphocytes (CD3). Microvascular density was measured by two independent observers who counted all CD31-stained blood vessels in 10 high-power fields (HPFs) randomly selected within the tumor region. The average number of blood vessels per HPF was then calculated and used in subsequent analysis. For CD3, slides were scanned using the Pannoramic MIDI digital scanner (3DHISTECH Ltd., Budapest, Hungary) and then viewed at $\times 10$ magnification using the MIRAX Viewer 1.11 (3DHISTECH Ltd.). For each tumor, four to six representative areas of $1,800 \mu \mathrm{m}$ $\times 1,200 \mu \mathrm{m}$ were selected, and the tumor and surrounding stroma were separately analyzed using ImageJ software and the color deconvolution plug-in [19]. The area covered by the antibody was measured and normalized by dividing it by the area covered by nuclei.

\section{Statistical analysis}

The distribution of the SNP genotypes was studied using an Excel-based Hardy-Weinberg equilibrium (HWE) calculator [20]. For all other statistical analyses, we used PASW Statistics version 17.0 software (SPSS Inc., Nieuwegein, The Netherlands).

\section{Results}

A total of 68 skin fibroblast cultures, 44 breast fibroblast cultures, 11 tumor-derived fibroblast cultures and 25 skin epithelial cell cultures were established from 98 patients who had undergone breast cancer-related surgery at LUMC. We genotyped four SNPs in intron 2 of FGFR2 (Table 6). All SNPs were in HWE. SNP rs2981578 was chosen to represent all four SNPs because of its reported effect on the binding of transcription factor Runx2 and because it showed strong LD with the other three SNPs including rs2981582.
FGFR2 mRNA expression in fibroblasts and epithelial cells A significant correlation between the rs2981578 genotype and FGFR2 mRNA expression level as measured by qRT-PCR was present in the 68 skin fibroblast cultures (Figure $1 \mathrm{~A})(P=0.02$; one-way analysis of variance (ANOVA)). Although expression levels varied widely within each genotype group, a dosage-dependent effect was seen, with the highest average expression found among homozygotes for the minor allele (the risk allele), followed by heterozygotes, and the lowest average expression found among homozygotes for the major allele. In contrast, among 25 skin epithelial cell cultures, there were no statistically significant differences in FGFR2 mRNA expression levels between the three genotype groups, although the average levels of FGFR2 mRNA were slightly lower in carriers of one or two copies of the risk allele (Figure $1 \mathrm{~B})(P=0.732$; one-way ANOVA).

\begin{tabular}{lcccc}
\multicolumn{4}{l}{ Table $\mathbf{6}$ Genotype distribution of four SNPs in FGFR2 } \\
\hline rs2981582 & rs2981578 & rs10736303 & rs7895676 & $\begin{array}{c}\text { Number of } \\
\text { patients }\end{array}$ \\
\hline $\mathrm{CT}$ & $\mathrm{AG}$ & $\mathrm{AG}$ & $\mathrm{CT}$ & 29 \\
$\pi \mathrm{C}$ & $\mathrm{GG}$ & $\mathrm{GG}$ & $\mathrm{CC}$ & 22 \\
$\mathrm{CC}$ & $\mathrm{AA}$ & $\mathrm{AA}$ & $\pi$ & 21 \\
$\mathrm{CT}$ & $\mathrm{GG}$ & $\mathrm{GG}$ & $\mathrm{CC}$ & 7 \\
$\mathrm{CC}$ & $\mathrm{AG}$ & $\mathrm{AG}$ & $\mathrm{CT}$ & 5 \\
$T T$ & $\mathrm{AA}$ & $\mathrm{AA}$ & $\mathrm{TT}$ & 1 \\
Total & & & & $85^{\mathrm{b}}$ \\
\hline
\end{tabular}

${ }^{a} F G F R 2$ f fibroblast growth factor receptor 2 gene. The number of patients who carry each combination of the four genotypes is shown in the right-hand column. Although we have no haplotype information, the genotype distribution shows the strong linkage disequilibrium present within this region. The alleles associated with increased breast cancer risk are rs2981582: T; rs2981578: G; rs10736303: G; and rs7895676: C. ${ }^{b}$ For the remaining13 patients, only rs2981578 was genotyped; of these patients, 5 carried AA, 5 carried AG and 3 carried GG. 


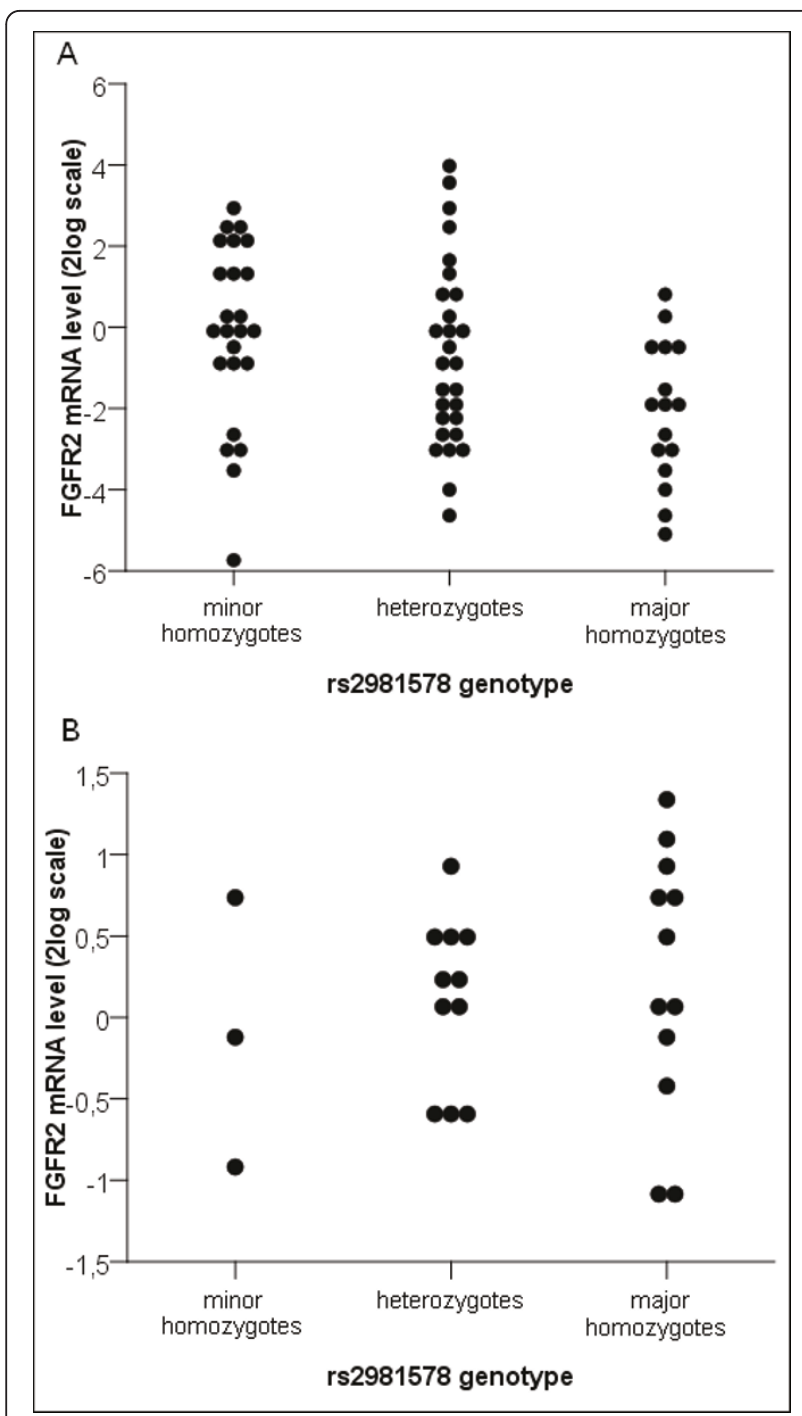

Figure 1 The relationship between FGFR2 mRNA expression and the rs2981578 genotype in skin fibroblast and skin epithelial cell cultures. (A) A significant correlation between the rs2981578 genotype and FGFR2 mRNA expression level as measured by quantitative real-time PCR was present in the 68 skin fibroblast cultures ( $P=0.02$; one-way ANOVA). The expression levels were $\log _{2}$-transformed and normalized to HNRPM and TBP expression. (B) FGFR2 mRNA expression and rs2981578 genotypes in 25 skin epithelial cell cultures ( $P=0.73$; one-way ANOVA). The expression levels were $\log _{2}$-transformed and normalized to HNRPM, SRPR and TBP expression. Each dot represents the expression level in one patient.

\section{FGFR2 mRNA expression in fibroblasts derived from different tissues}

To address whether FGFR2 expression levels in skin fibroblasts correlated to those in breast fibroblasts, we cultured fibroblasts from the skin tissue as well as the normal breast tissue from 22 breast cancer patients. There was a significant correlation between the FGFR2 mRNA levels in the skin fibroblasts and the breast fibroblasts (Figure 2A) (Pearson's correlation coefficient $=0.64, P=0.001)$. Expression levels were on average 2.8 times higher in the breast fibroblasts than in the skin fibroblasts $(P=0.001$; paired $t$-test).

For 11 of these 22 patients, we also successfully grew fibroblasts from the tumor tissue. FGFR2 mRNA expression in tumor-derived fibroblasts was on average eight times higher than in breast fibroblasts and sixteen times higher than in skin fibroblasts (Figure $2 \mathrm{~B})\left(P=3 \times 10^{-4}\right.$ and $P=2 \times 10^{-4}$, respectively; paired $t$-tests).

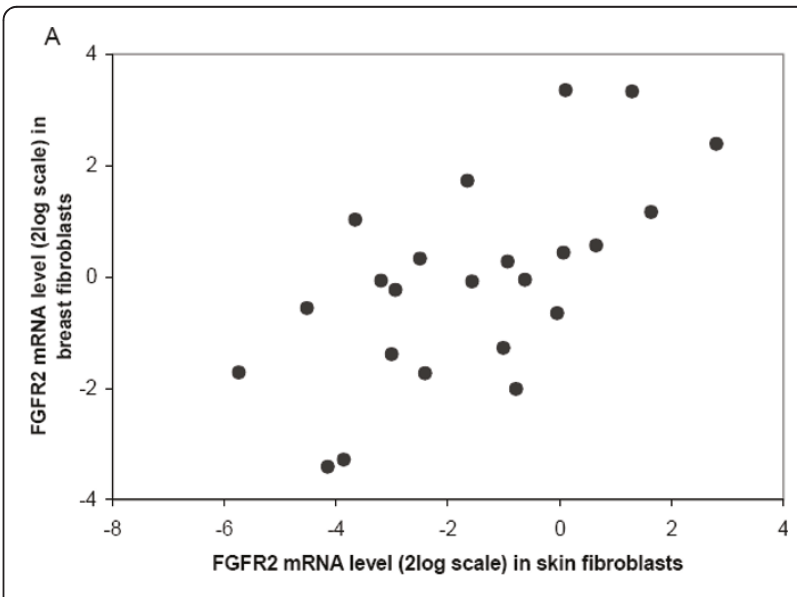

B

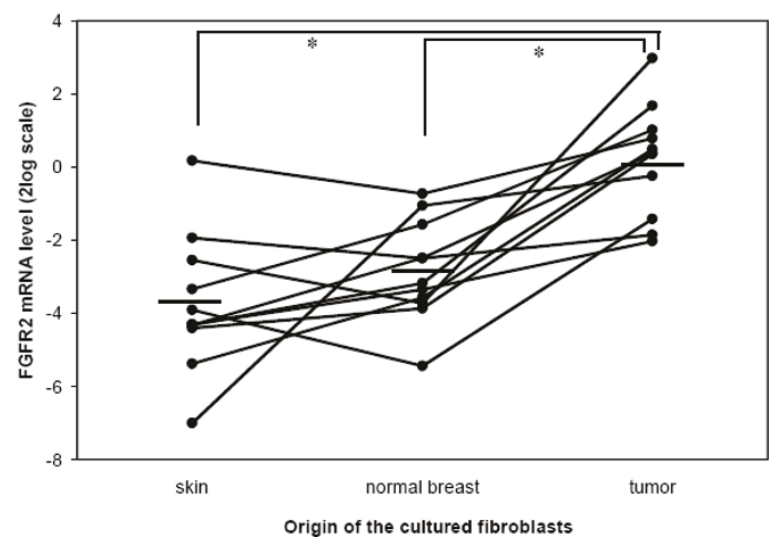

Figure 2 FGFR2 mRNA expression levels in fibroblasts cultured from different locations. (A) We found a significant correlation between FGFR2 mRNA expression in skin fibroblasts and normal breast fibroblasts from the same patient $(n=22)$. The FGFR2 expression levels were $\log _{2}$-transformed and normalized to HNRPM and TBP expression. (B) FGFR2 mRNA expression in tumor-derived fibroblasts is significantly higher than in fibroblasts cultured from normal breast tissue. The FGFR2 expression levels were $\log _{2}{ }^{-}$ transformed and normalized to HNRPM and TBP expression. Each dot represents FGFR2 expression in one patient. The lines connect the fibroblast cultures from one patient. The horizontal bars shows the mean expression for all fibroblast cultures from that origin (skin -3.8 ( \pm 1.9 SD), normal breast $-2.9( \pm 1.4 \mathrm{SD})$, tumor tissue $0.2( \pm 1.5$ SD)). ${ }^{*} P<0.001$. 
FGFR2 mRNA isoform expression analysis in fibroblasts and epithelial cells

Since an isoform switch from FGFR2 IIIb to FGFR2 IIIc has been reported in a few breast cancer cell lines, and since this switch may contribute to tumor development, we explored whether rs2981578 genotype influences the alternative splicing of isoforms of FGFR2. The expected FGFR2-IIIb was detected in 14 epithelial cell cultures, and the expected FGFR2-IIIc was detected in 48 of 52 fibroblast cultures. In the remaining four fibroblast samples, FGFR2-IIIb was present at a level approximately $10 \%$ of that of FGFR2-IIIc, but the presence or absence of FGFR2-IIIb was not associated with rs2981578 genotype $\left(P=0.32\right.$; Pearson's $\chi^{2}$ test $)$.

\section{Correlation between FGFR2 and FGF10 mRNA expression}

To explore a possible paracrine relationship between fibroblasts and epithelial cells, the mRNA expression levels of FGF2, FGF7 and FGF10 were measured in the 68 skin fibroblast cultures and compared to their FGFR2 mRNA expression. FGF2 mRNA expression was not correlated with FGFR2 expression (Figure 3C) (Pearson's correlation coefficient $=0.22, P=0.07$ ). The correlation between FGFR2 and FGF7 mRNA levels in skin fibroblasts did not remain significant after correction for multiple testing (Figure 3B) (Pearson's correlation coefficient $=0.28, P=0.02$ ).

FGFR2 and FGF10 expression levels were loosely but significantly correlated in the skin fibroblast cultures (Figure 3A) (Pearson's correlation coefficient $=0.60, P=$ $\left.8 \times 10^{-8}\right)$. There was also a suggestive correlation between FGF10 expression and rs2981578 genotype in these cultures ( $P=0.06$; one-way ANOVA) (Figure S3 in Additional file 4). In 44 fibroblast cultures from normal breast tissue, there was a suggestive correlation between FGFR2 and FGF10 mRNA levels (Spearman's $\rho$ $=0.25, P=0.11)$ (Figure S4 in Additional file 5).

\section{FGFR2 protein expression}

In seven fibroblast cultures, FGFR2 protein levels were quantified by Western blot analysis and compared with the FGFR2 mRNA levels. The FGFR2 antibody that was used detected a full-length FGFR2 recombinant protein, but absolute protein expression levels in fibroblasts were very low, giving poor signal-to-noise ratios. Possibly as a result of this, we were unable to demonstrate a correlation between FGFR2 mRNA and protein levels (Spearman's $\rho=-0.14, P=0.76$ ) (Figure S5 in Additional file 6).

\section{Phosphorylation of downstream FGFR2 targets}

To investigate whether the differences in FGFR2 mRNA expression levels correspond with different levels of FGFR2 pathway activity, we compared the phosphorylation of downstream targets FGF receptor substrate $2 \alpha$

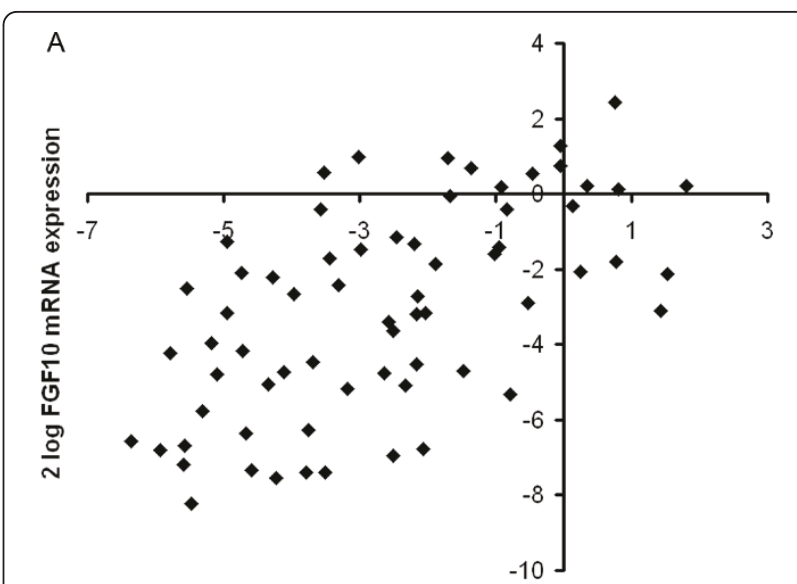

2log FGFR2 mRNA expression

B

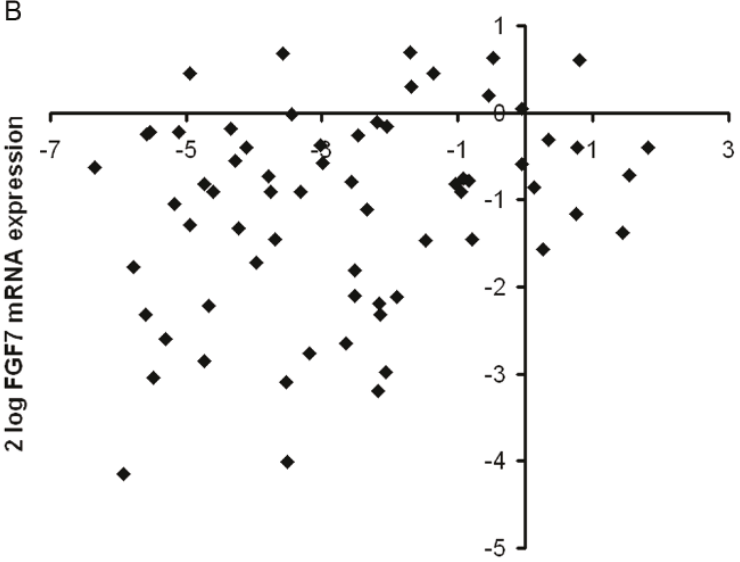

2log FGFR2 mRNA expression

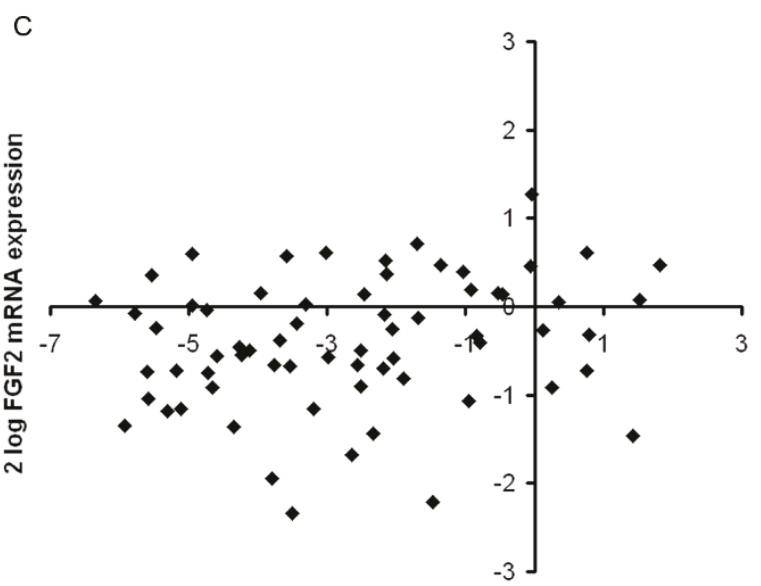

2log FGFR2 mRNA expression

Figure 3 Correlation of expression levels of FGFR2 and FGF10 mRNA in 68 skin fibroblast cultures. No correlation was found for FGFR2 and FGF2 mRNA or FGFR2 and FGF7 mRNA levels. The data were normalized to HNRPM and TBP and $\log _{2}$-transformed. Each dot represents the expression levels from one patient. (A) FGFR2 and FGF10 ( $P=8 \times 10^{-8}$; Pearson's correlation). (B) FGFR2 and FGF7 ( $P=$ 0.02; Pearson's correlation). (C) FGFR2 and FGF2 ( $P=0.07$; Pearson's correlation) 
(FRS2 $\alpha$ ) and extracellular signal-regulated kinases 1 and 2 (ERK1/2) after 10 minutes of exposure to ligand FGF2 in skin fibroblast cultures with high and low FGFR2 mRNA levels. Duplicate measurements correlated well in all experiments (Pearson's correlation coefficient = 0.92, $P=8 \times 10^{-65}$ ).

Phosphorylation of FRS2 $\alpha$ was measured in four fibroblast cultures, two with high and two with low FGFR2 expression. The sample with higher FGFR2 expression showed a larger increase in phosphorylation of FRS $2 \alpha$ after FGF2 was added compared to the sample with lower FGFR2 expression (Figure 4$)(P=0.18$; Wilcoxon signed-rank test).

Phosphorylation of ERK1/2 increased in all skin fibroblast cultures after exposure to FGF2, and this effect was again more pronounced in the sample with higher FGFR2 expression in all five experiments (Figure 4) $(P=$ 0.04; Wilcoxon signed-rank test).

\section{FGFR2 mRNA level and histological breast tumor characteristics}

We explored tumor parameters in patients with different FGFR2 mRNA levels in their fibroblasts. Since the percentage of stroma in the primary tumor may vary considerably [18] and FGFR2 signaling in the stroma could influence cell proliferation, we explored whether patients with higher FGFR2 mRNA expression in fibroblasts had a higher stroma percentage. In the 50 patients

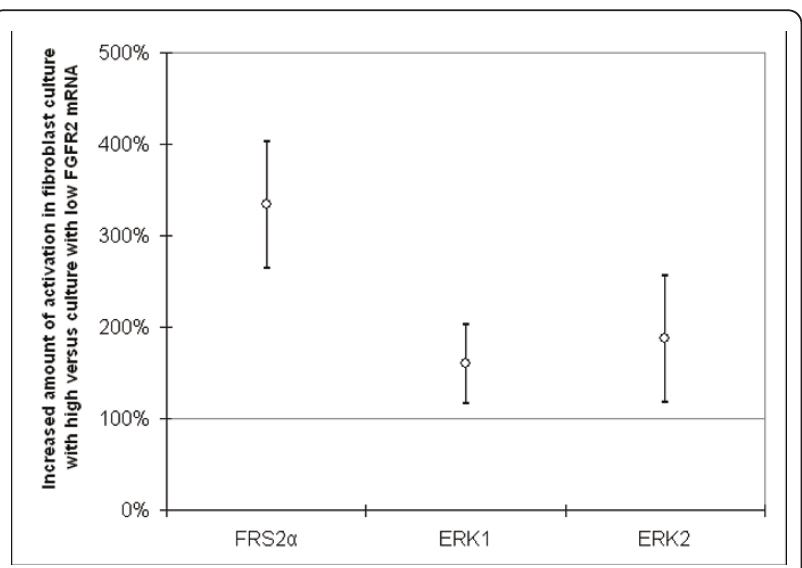

Figure 4 Response of skin fibroblast cultures with high and low FGFR2 mRNA levels to stimulation with ligand FGF2.

Phosphorylation of downstream targets FRS2 $\alpha$ and ERK1/2 were measured before and after 10 minutes of stimulation with FGF2.

The average difference of the increase in phosphorylation is shown, which was calculated by dividing the increase in samples with high FGFR2 mRNA levels by the increase in samples with low FGFR2 mRNA levels. The 95\% confidence intervals are also shown. Phosphorylation of FRS2 $\alpha$ was measured in four fibroblast cultures: two with high and two with low FGFR2 mRNA levels.

Phosphorylation of ERK1/2 was measured in 10 fibroblast cultures, five with high and five with low FGFR2 mRNA levels. analyzed, no correlation was present between FGFR2 mRNA levels in their fibroblasts and the percentage of stroma within the tumor (Spearman's $\rho=0.17, P=$ 0.23). Unfortunately, not enough tumor tissue was available from patients from whom we had obtained skin epithelial cells.

Because FGF signaling in cancer has been associated with induction of angiogenesis and lymphocytic infiltration [21], the number of microvessels was determined and T-cell infiltrate was quantified in breast tumors from patients whose fibroblasts had relatively high $(n=$ 11 ) or relatively low $(n=14)$ FGFR2 expression. Interobserver agreement regarding the number of blood vessels per HPF was high (Pearson's correlation coefficient $=0.89, P=1 \times 10^{-5}$ ), but no correlation with FGFR2 mRNA levels was present (Pearson's correlation coefficient $=0.04, P=0.86)$. No correlations between the amount of T-cell infiltrate and FGFR2 mRNA levels in the fibroblasts were detected either ( $\mathrm{T}$ cells in stroma: Pearson's correlation coefficient $=0.04, P=0.86$; T cells in tumor: Pearson's correlation coefficient $=0.15, P=$ 0.52).

Finally, since the SNPs in intron 2 of FGFR2 are mainly associated with estrogen receptor-positive (ERpositive) breast tumors $[1,22]$, we studied a possible correlation between FGFR2 mRNA levels and ER status of the tumor in 50 patients, but could detect none $(P=$ 0.60 ; logistic regression).

\section{Discussion}

Aberrant FGF signaling has been implicated in the pathogenesis of multiple types of cancer, including breast cancer $[11,23]$. Germline genetic variation in an LD region within intron 2 of FGFR2 has been associated with a modestly increased breast cancer risk. Fine-scale genetic mapping and functional analyses identified up to eight SNPs, including SNP rs2981578, as likely causal variants $[1,5,7]$. It was demonstrated that these SNPs influence mRNA expression levels of the FGFR2 gene. Despite this progress, substantial uncertainty remains regarding how subtle modulation of FGFR2 expression levels may modify breast cancer risk. In addition, opposite effects of intron 2 SNP genotypes on FGFR2 mRNA expression have been reported in tumor tissue and normal breast tissue $[7,8]$.

We found, on average, higher FGFR2 mRNA levels in skin fibroblast cultures of heterozygotes and homozygotes for the risk allele of SNP rs2981578 relative to homozygotes for the major allele. This is in agreement with measurements of FGFR2 mRNA expression in total RNA from breast tumor tissue [7]. However, no effect of genotype was observed in our skin epithelial cell cultures. Also, epithelial breast tumor cells express lower levels of FGFR2 than surrounding normal breast 
epithelium [12]. Soluble factors secreted or recruited by tumor cells may induce expression changes in neighboring normal cells, leading to gene expression differences between tumor-derived stromal fibroblasts and normal breast stroma [24]. In the 11 patients from whom we obtained fibroblasts from skin, normal breast tissue and breast tumor tissue, FGFR2 expression levels in the tumor-derived fibroblasts were consistently higher than in the fibroblasts from normal breast tissue. A similar finding was made recently in cell cultures from patients with esophageal cancer [25]. Unfortunately, our sample set was too small to conclusively establish whether expression levels of FGFR2 mRNA in tumor-derived fibroblasts are similarly associated with SNP genotypes in intron 2 as they are in skin-derived fibroblasts. Taken together, however, these data suggest that the association between genotype and FGFR2 expression observed by Meyer et al. [7] in total breast tumor homogenates was derived from cancer-associated fibroblasts rather than from the tumor (or epithelial) component. Because the transcription factors Oct-1/Runx2 and C/EBP $\beta$ display differential binding to these SNP alleles in epithelial breast tumor cells, it will be interesting to study this in other cell types constituting breast tumor stroma.

Our results in fibroblast and epithelial cell cultures are at odds with those obtained by Sun et al. [8], who reported lower FGFR2 mRNA expression in normal breast tissue from homozygotes for the risk allele. However, the differences reported by Sun et al. were small and the correlation was weak. In our epithelial cell cultures, there was a trend toward lower FGFR2 mRNA expression in carriers of one or two copies of the risk allele, but the differences were very small. The insufficient statistical power of our studies or the differences in experimental design (whole tissue analysis versus analysis of cultured epithelial cells) may underlie these different outcomes.

The variation in FGFR2 mRNA expression between individuals with the same intron 2 genotype is wide in both fibroblasts and epithelial cells. Apparently, the causal variants in intron 2 of FGFR2 only partly determine the FGFR2 mRNA expression level. We have shown that in skin fibroblasts, higher FGFR2 mRNA levels correspond to higher activity of the FGFR2 pathway upon stimulation by ligand FGF2, indicating that the allelic status of the intron 2 SNPs is functional at the FGF signaling level. Cells with higher FGFR2 expression probably respond differently to the same fibroblast growth factor concentration in their microenvironment [26]. Thus, the overall activity of the FGFR2 pathway might be a more accurate predictor of breast cancer risk than rs2981578 or rs2981582 genotype status, although it is presently unclear through which cell type and in which developmental phase of the mammary gland this activity contributes most to this risk.
Fibroblasts have a well-recognized role in the carcinogenic process as remodelers of the extracellular matrix in tumor stroma and as a source of paracrine growth factors that influence the growth of carcinoma cells $[27,28]$. Unequivocal evidence that paracrine FGF released from breast tumor stroma functions to promote tumorigenesis is lacking, but, intriguingly, we found a strong correlation between FGFR2 and FGF10 mRNA expression levels in the cultured skin fibroblasts. We have not investigated the mechanism underlying this correlation, nor have we been able to establish that it also holds true for tumor-derived fibroblasts. Since FGF10 is known to be secreted by fibroblasts and to bind specifically to the FGFR2-IIIb isoform expressed on epithelial cells, however, our findings would fit a model of paracrine tumor-stroma interaction. The FGFR2-IIIbFGF10 interaction plays a key role in the normal embryological and postnatal development of the mammary glands in mice [29,30]. Mice deficient in Fgf10 or Fgfr $2 b$ fail to develop normal mammary glands. Apparently, Fgfr2b signaling is crucial for the survival and proliferation of the mammary luminal epithelial cells but does not affect the regenerative potential of the mammary epithelial progenitor cells. Fgf10 overexpression in the stromal compartment of the murine prostate results in epithelial cell hyperproliferation [31]. Also, in humans, FGF10 is thought to stimulate epithelial cell proliferation [32].

Thus, it is conceivable that, in the human breast, slightly increased levels of FGFR2 and FGF10 result in a slightly increased ductal branching. If this primarily involved the luminal epithelial component of the breast tissue as it does in mice, this would explain why the increased breast cancer risk conferred by FGFR2 intron 2 SNPs is mostly restricted to ER-positive tumors $[22,33]$. High FGF2 and/or FGFR2 protein levels have been correlated with high ER levels in breast cancer $[34,35]$. Our cohort was probably underpowered to demonstrate a correlation between ER status of the tumor and FGFR2 mRNA expression levels in skin fibroblasts. FGF7, also secreted by breast fibroblasts, has similarly been suggested to act as a paracrine growth factor in human breast cancer [36], but our data do not demonstrate a significant link between FGF7 and FGFR2 expression.

In pancreatic cancer, FGF10 is found in stromal cells, close to the tumor cells, and is thought to interact with FGFR2-IIIb on the tumor cells, thereby inducing cell migration and invasion [37]. Since the downstream effects of activation of FGFR2 by different FGFs in different cell types are very diverse and could include apoptosis, cell proliferation and angiogenesis [11], it is difficult to predict which of these effects could mechanistically explain the increased breast cancer risk 
associated with intron 2 SNPs. Here we have explored some of the end points of these processes in breast tumors from patients with different FGFR2 mRNA levels in their fibroblasts. Tsunoda et al. [38] reported increased T-lymphocyte and macrophage infiltration into a newly inoculated tumor when they injected FGF2 into this tumor. In mice, overexpression of Fgf10 leads to highly vascularized tumors in immunocompetent mice [39]. However, we found no correlation between FGFR2 mRNA levels and, respectively, stroma percentage of the tumor, microvessel density and T-cell infiltrate. Our sample size may have been too small to detect any existing differences, in particular because these differences can be expected to be small, given the mildly increased breast cancer risks conferred by FGFR 2 SNPs.

A limitation of our study is that our observations were based on cultured cells from surgically removed tissues. Culture conditions between fibroblasts and epithelial cells were necessarily different and may have influenced some of our findings, but this enabled us to study RNA expression levels by cell type instead of by heterogeneous tissue. It has long been known that the phenotype of fibroblasts can differ depending on anatomical site [40-43]. Indeed, we did observe absolute differences in FGFR2 mRNA expression levels between fibroblasts from skin tissue and those from normal breast tissue, but we demonstrated that these correlate very well (Figure 2).

\section{Conclusions}

In conclusion, it is likely that the causative variants tagged by rs 2981578 in intron 2 of the FGFR 2 gene cause a higher breast cancer risk by influencing FGFR2 expression levels. Here we have shown that the effect of intron 2 SNPs on FGFR2 expression is cell type-specific. Different effects were observed in skin fibroblasts and epithelial cells. Tissue specificity for expression quantitative trait loci is common [44] and clearly also applies to FGFR2.

In addition, we observed differences in the levels of FGFR2 mRNA expression between fibroblasts derived from normal breast tissue or from tumor tissue, which strongly supports a holistic model to explain FGFR2related breast cancer risk [45] rather than one assuming cell autonomous effects of FGFR2 expression modulation. Our finding that individuals in whom intrinsically higher levels of FGFR2 are expressed in their skin fibroblasts also have higher levels of FGF10 suggests that the increased breast cancer risk might be due to a stronger paracrine effect between stromal and tumor cells involving FGF10 signaling. The fact that the association between FGFR2 and FGF10 expression was not observed by Meyer et al. [7] in 45 normal breast tissue samples underscores the importance of analyzing the various constituting cell types separately in sufficiently large cohorts. Since we limited our search for such associations to FGFs secreted by fibroblasts, and given that the FGFR2 and FGF10 genes are located on different chromosomes, it will be important to extend these analyses to genome-wide expression differences between different cell types in various FGFR2 genotype backgrounds.

\section{Additional material}

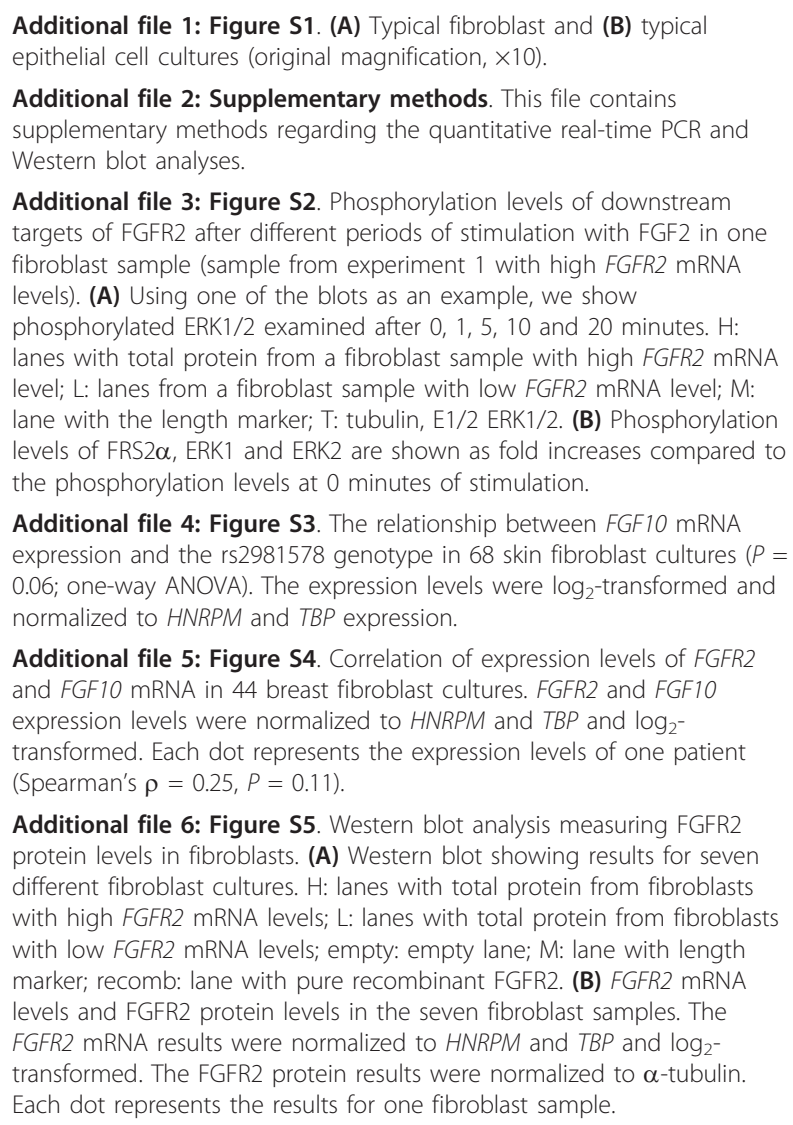

Additional file 5: Figure S4. Correlation of expression levels of FGFR2 and FGF10 mRNA in 44 breast fibroblast cultures. FGFR2 and FGF10 expression levels were normalized to HNRPM and TBP and $\log _{2^{-}}$ transformed. Each dot represents the expression levels of one patient (Spearman's $\rho=0.25, P=0.11$ ).

Additional file 6: Figure S5. Western blot analysis measuring FGFR2 protein levels in fibroblasts. (A) Western blot showing results for seven different fibroblast cultures. H: lanes with total protein from fibroblasts with high FGFR2 mRNA levels; L: lanes with total protein from fibroblasts with low FGFR2 mRNA levels; empty: empty lane; M: lane with length marker; recomb: lane with pure recombinant FGFR2. (B) FGFR2 mRNA levels and FGFR2 protein levels in the seven fibroblast samples. The FGFR2 mRNA results were normalized to HNRPM and TBP and $\log _{2^{-}}$ transformed. The FGFR2 protein results were normalized to $\alpha$-tubulin. Each dot represents the results for one fibroblast sample.

\section{Abbreviations}

bp: base pairs; C/EBP $\beta$ : CCAAT/enhancer binding protein $\beta$; Cl: confidence interval; ER: estrogen receptor; ERK1/2: extracellular signal-regulated kinases 1 and 2; FCS: fetal calf serum; FGFR2: fibroblast growth factor receptor 2 gene; FGF: fibroblast growth factor; FRS2a: fibroblast growth factor receptor substrate 2a; $\mathrm{H}$ \& E: hematoxylin and eosin; HNRPM: heterogeneous nuclear ribonucleoprotein M; HPF: high-power field; HWE: Hardy-Weinberg equilibrium; LD: linkage disequilibrium; MAPK: mitogen-activated protein kinase; Oct-1: octamer-binding transcription factor 1; OR: odds ratio; PCR: polymerase chain reaction; qPCR: quantitative real-time PCR; Runx2: runtrelated transcription factor 2; SNP: single-nucleotide polymorphism; SRPR: signal recognition particle receptor; TBP: TATA box binding protein.

\section{Acknowledgements}

The authors thank JJ Baelde, EJ Dreef, FA Prins and KR Straasheijm for their technical assistance and EMM Krol Warmerdam for patient recruitment. This work was supported by the Dutch Cancer Society (grant 2006-3477). The 
funders had no role in the study design, data collection and analysis, decision to publish or preparation of the manuscript.

\section{Author details}

'Department of Clinical Genetics, Leiden University Medical Center, PO Box 9600, 2300 RC Leiden, The Netherlands. '2Department of Human Genetics, Leiden University Medical Center, PO Box 9600, 2300 RC Leiden, The Netherlands. ${ }^{3}$ Department of Surgery, Leiden University Medical Center, PO Box 9600, 2300 RC Leiden, The Netherlands. ${ }^{4}$ Department of Medical Statistics and Bioinformatics, Leiden University Medical Center, PO Box 9600, 2300 RC Leiden, The Netherlands. ${ }^{5}$ Department of Pathology, Leiden University Medical Center, PO Box 9600, 2300 RC Leiden, The Netherlands.

\section{Authors' contributions}

The experiments were performed by PH, MD, MG and AM. The patient material was provided by RT and VS. The cells were cultured by FB and MV. The stroma percentage of 50 tumors was analyzed by EK and WM. The experiments were designed, analyzed and interpreted by PH, CA and PD. EZ helped with the statistical analyses and the interpretation of the data. The manuscript was drafted by PH and critically revised by MV, CA and PD. All authors read and approved the final manuscript.

\section{Competing interests}

The authors declare that they have no competing interests.

Received: 14 December 2010 Revised: 13 May 2011

Accepted: 18 July 2011 Published: 18 July 2011

\section{References}

1. Easton DF, Pooley KA, Dunning AM, Pharoah PD, Thompson D, Ballinger DG, Struewing JP, Morrison J, Field H, Luben R, Wareham N, Ahmed S, Healey CS, Bowman R, SEARCH collaborators, Meyer KB, Haiman CA, Kolonel LK, Henderson BE, Le Marchand L, Brennan P, Sangrajrang S, Gaborieau V, Odefrey F, Shen CY, Wu PE, Wang HC, Eccles D, Evans DG, et al: Genome-wide association study identifies novel breast cancer susceptibility loci. Nature 2007, 447:1087-1093.

2. Hunter DJ, Kraft P, Jacobs KB, Cox DG, Yeager M, Hankinson SE, Wacholder S, Wang Z, Welch R, Hutchinson A, Wang J, Yu K, Chatterjee N, Orr N, Willett WC, Colditz GA, Ziegler RG, Berg CD, Buys SS, McCarty CA, Feigelson HS, Calle EE, Thun MJ, Hayes RB, Tucker M, Gerhard DS, Fraumeni JF Jr, Hoover RN, Thomas G, Chanock SJ: A genome-wide association study identifies alleles in FGFR2 associated with risk of sporadic postmenopausal breast cancer. Nat Genet 2007, 39:870-874.

3. Kawase T, Matsuo K, Suzuki T, Hiraki A, Watanabe M, Iwata H, Tanaka H, Tajima K: FGFR2 intronic polymorphisms interact with reproductive risk factors of breast cancer: results of a case control study in Japan. Int J Cancer 2009, 125:1946-1952.

4. Liang J, Chen P, Hu Z, Zhou X, Chen L, Li M, Wang Y, Tang J, Wang H, Shen $\mathrm{H}$ : Genetic variants in fibroblast growth factor receptor 2 (FGFR2) contribute to susceptibility of breast cancer in Chinese women. Carcinogenesis 2008, 29:2341-2346.

5. Udler MS, Meyer KB, Pooley KA, Karlins E, Struewing JP, Zhang J, Doody DR, MacArthur S, Tyrer J, Pharoah PD, Luben R, Bernstein L, Kolonel LN, Henderson BE, Le Marchand L, Ursin G, Press MF, Brennan P, Sangrajrang S, Gaborieau V, Odefrey F, Shen CY, Wu PE, Wang HC, Kang D, Yoo KY, Noh DY, Ahn SH, Ponder BA, Haiman CA, SEARCH Collaborators: FGFR2 variants and breast cancer risk: fine-scale mapping using African American studies and analysis of chromatin conformation. Hum Mol Genet 2009, 18:1692-1703.

6. Zheng W, Cai Q, Signorello LB, Long J, Hargreaves MK, Deming SL, Li G, Li C, Cui Y, Blot WJ: Evaluation of 11 breast cancer susceptibility loci in African-American women. Cancer Epidemiol Biomarkers Prev 2009, 18:2761-2764.

7. Meyer KB, Maia AT, O'Reilly M, Teschendorff AE, Chin SF, Caldas C Ponder BA: Allele-specific up-regulation of FGFR2 increases susceptibility to breast cancer. PLOS Biol 2008, 6:e108.

8. Sun C, Olopade OI, Di RA: rs2981582 is associated with FGFR2 expression in normal breast. Cancer Genet Cytogenet 2010, 197:193-194.

9. Eswarakumar VP, Lax I, Schlessinger J: Cellular signaling by fibroblast growth factor receptors. Cytokine Growth Factor Rev 2005, 16:139-149.
10. Knights V, Cook SJ: De-regulated FGF receptors as therapeutic targets in cancer. Pharmacol Ther 2010, 125:105-117.

11. Turner N, Grose R: Fibroblast growth factor signalling: from development to cancer. Nat Rev Cancer 2010, 10:116-129.

12. Zhu X, Asa SL, Ezzat S: Genetic and epigenetic mechanisms downregulate FGF receptor 2 to induce melanoma-associated antigen $A$ in breast cancer. Am J Pathol 2010, 176:2333-2343.

13. Penault-Llorca F, Bertucci F, Adélaïde J, Parc P, Coulier F, Jacquemier J, Birnbaum $D$, deLapeyrière $O$ : Expression of $F G F$ and $F G F$ receptor genes in human breast cancer. Int J Cancer 1995, 61:170-176.

14. Stephens P, Edkins S, Davies H, Greenman C, Cox C, Hunter C, Bignell G, Teague J, Smith R, Stevens C, O'Meara S, Parker A, Tarpey P, Avis T, Barthorpe A, Brackenbury L, Buck G, Butler A, Clements J, Cole J, Dicks E, Edwards K, Forbes S, Gorton M, Gray K, Halliday K, Harrison R, Hills K, Hinton J, Jones $D$, et al: A screen of the complete protein kinase gene family identifies diverse patterns of somatic mutations in human breast cancer. Nat Genet 2005, 37:590-592.

15. Kwabi-Addo B, Ropiquet F, Giri D, Ittmann M: Alternative splicing of fibroblast growth factor receptors in human prostate cancer. Prostate 2001, 46:163-172.

16. Luqmani YA, Bansal GS, Mortimer C, Buluwela L, Coombes RC: Expression of FGFR2 BEK and K-SAM mRNA variants in normal and malignant human breast. Eur J Cancer 1996, 32A:518-524.

17. Zhu X, Asa SL, Ezzat S: Histone-acetylated control of fibroblast growth factor receptor 2 intron 2 polymorphisms and isoform splicing in breast cancer. Mol Endocrinol 2009, 23:1397-1405.

18. de Kruijf EM, van Nes JG, van de Velde CJ, Putter H, Smit VT, Liefers GJ, Kuppen PJ, Tollenaar RA, Mesker WE: Tumor-stroma ratio in the primary tumor is a prognostic factor in early breast cancer patients, especially in triple-negative carcinoma patients. Breast Cancer Res Treat 2011, 125:687-696.

19. Ruifrok AC, Johnston DA: Quantification of histochemical staining by color deconvolution. Anal Quant Cytol Histol 2001, 23:291-299.

20. Court lab HW calculator. [http://www.tufts.edu/ mcourt01/Documents/ Court\%20lab\%20-\%20HW\%20calculator.xls].

21. Acevedo VD, Ittmann M, Spencer DM: Paths of FGFR-driven tumorigenesis. Cell Cycle 2009, 8:580-588.

22. Garcia-Closas M, Hall P, Nevanlinna H, Pooley K, Morrison J, Richesson DA, Bojesen SE, Nordestgaard BG, Axelsson CK, Arias Jl, Milne RL, Ribas G, González-Neira A, Benítez J, Zamora P, Brauch H, Justenhoven C, Hamann U, Ko YD, Bruening T, Haas S, Dörk T, Schürmann P, Hillemanns $P$, Bogdanova N, Bremer M, Karstens JH, Fagerholm R, Aaltonen K, Aittomäki K, et al: Heterogeneity of breast cancer associations with five susceptibility loci by clinical and pathological characteristics. PLoS Genet 2008, 4: e1000054.

23. Katoh M: Cancer genomics and genetics of FGFR2. Int J Oncol 2008, 33:233-237.

24. Singer CF, Gschwantler-Kaulich D, Fink-Retter A, Haas C, Hudelist G, Czerwenka K, Kubista E: Differential gene expression profile in breast cancer-derived stromal fibroblasts. Breast Cancer Res Treat 2008, 110:273-281.

25. Zhang C, Fu L, Fu J, Hu L, Yang H, Rong TH, Li Y, Liu H, Fu SB, Zeng YX Guan $X Y$ : Fibroblast growth factor receptor 2-positive fibroblasts provide a suitable microenvironment for tumor development and progression in esophageal carcinoma. Clin Cancer Res 2009, 15:4017-4027.

26. Garcia-Maya M, Anderson AA, Kendal CE, Kenny AV, Edwards-Ingram LC, Holladay A, Saffell JL: Ligand concentration is a driver of divergent signaling and pleiotropic cellular responses to FGF. J Cell Physiol 2006, 206:386-393

27. Bhowmick NA, Neilson EG, Moses HL: Stromal fibroblasts in cancer initiation and progression. Nature 2004, 432:332-337.

28. Kalluri R, Zeisberg M: Fibroblasts in cancer. Nat Rev Cancer 2006, 6:392-401.

29. Mailleux AA, Spencer-Dene B, Dillon C, Ndiaye D, Savona-Baron C, Itoh N, Kato S, Dickson C, Thiery JP, Bellusci S: Role of FGF10/FGFR2b signaling during mammary gland development in the mouse embryo. Development 2002, 129:53-60.

30. Parsa S, Ramasamy SK, De Langhe S, Gupte W, Haigh JJ, Medina D, Bellusci S: Terminal end bud maintenance in mammary gland is dependent upon FGFR2b signaling. Dev Biol 2008, 317:121-131.

31. Abate-Shen C, Shen MM: FGF signaling in prostate tumorigenesis: new insights into epithelial-stromal interactions. Cancer Cell 2007, 12:495-497. 
32. Katoh M, Katoh M: FGFR2 and WDR11 are neighboring oncogene and tumor suppressor gene on human chromosome 10q26. Int J Oncol 2003, 22:1155-1159.

33. Stacey SN, Manolescu A, Sulem P, Thorlacius S, Gudjonsson SA, Jonsson GF, Jakobsdottir M, Bergthorsson JT, Gudmundsson J, Aben KK, Strobbe LJ, Swinkels DW, van Engelenburg KC, Henderson BE, Kolonel LN, Le Marchand L, Millastre E, Andres R, Saez B, Lambea J, Godino J, Polo E, Tres A, Picelli S, Rantala J, Margolin S, Jonsson T, Sigurdsson H, Jonsdottir T, Hrafnkelsson J, et al: Common variants on chromosome $5 \mathrm{p} 12$ confer susceptibility to estrogen receptor-positive breast cancer. Nat Genet 2008, 40:703-706.

34. Smith K, Fox SB, Whitehouse R, Taylor M, Greenall M, Clarke J, Harris AL: Upregulation of basic fibroblast growth factor in breast carcinoma and its relationship to vascular density, oestrogen receptor, epidermal growth factor receptor and survival. Ann Oncol 1999, 10:707-713.

35. Tozlu S, Girault I, Vacher S, Vendrell J, Andrieu C, Spyratos F, Cohen P, Lidereau R, Bieche I: Identification of novel genes that co-cluster with estrogen receptor a in breast tumor biopsy specimens, using a largescale real-time reverse transcription-PCR approach. Endocr Relat Cancer 2006, 13:1109-1120.

36. Hishikawa Y, Tamaru N, Ejima K, Hayashi T, Koji T: Expression of keratinocyte growth factor and its receptor in human breast cancer: its inhibitory role in the induction of apoptosis possibly through the overexpression of Bcl-2. Arch Histol Cytol 2004, 67:455-464.

37. Nomura S, Yoshitomi H, Takano S, Shida T, Kobayashi S, Ohtsuka M, Kimura F, Shimizu H, Yoshidome H, Kato A, Miyazaki M: FGF10/FGFR2 signal induces cell migration and invasion in pancreatic cancer. $\mathrm{Br} J$ Cancer 2008, 99:305-313.

38. Tsunoda S, Sakurai H, Saito Y, Ueno Y, Koizumi K, Saiki I: Massive Tlymphocyte infiltration into the host stroma is essential for fibroblast growth factor-2-promoted growth and metastasis of mammary tumors via neovascular stability. Am J Pathol 2009, 174:671-683.

39. Theodorou V, Boer M, Weigelt B, Jonkers J, van der Valk M, Hilkens J: Fgf10 is an oncogene activated by MMTV insertional mutagenesis in mouse mammary tumors and overexpressed in a subset of human breast carcinomas. Oncogene 2004, 23:6047-6055.

40. Sorrell JM, Caplan Al: Fibroblasts: a diverse population at the center of it all. Int Rev Cell Mol Biol 2009, 276:161-214.

41. Chang HY, Chi JT, Dudoit S, Bondre C, van de Rijn M, Botstein D, Brown PO: Diversity, topographic differentiation, and positional memory in human fibroblasts. Proc Natl Acad Sci USA 2002, 99:12877-12882.

42. Rinn JL, Bondre C, Gladstone HB, Brown PO, Chang HY: Anatomic demarcation by positional variation in fibroblast gene expression programs. PLoS Genet 2006, 2:e119.

43. Nolte SV, Xu W, Rennekampff HO, Rodemann HP: Diversity of fibroblasts: a review on implications for skin tissue engineering. Cells Tissues Organs 2008, 187:165-176

44. Huang GJ, Shifman S, Valdar W, Johannesson M, Yalcin B, Taylor MS, Taylor JM, Mott R, Flint J: High resolution mapping of expression QTLs in heterogeneous stock mice in multiple tissues. Genome Res 2009, 19:1133-1140.

45. Hanahan D, Weinberg RA: The hallmarks of cancer. Cell 2000, 100:57-70.

\section{doi:10.1186/bcr2917}

Cite this article as: Huijts et al: Allele-specific regulation of FGFR2 expression is cell type-dependent and may increase breast cancer risk through a paracrine stimulus involving FGF10. Breast Cancer Research 2011 13:R72.

\section{Submit your next manuscript to BioMed Central and take full advantage of:}

- Convenient online submission

- Thorough peer review

- No space constraints or color figure charges

- Immediate publication on acceptance

- Inclusion in PubMed, CAS, Scopus and Google Scholar

- Research which is freely available for redistribution 